\title{
Law Enforcement Workers
}

National Cancer Institute

\section{Source}

National Cancer Institute. Law Enforcement Workers. NCI Thesaurus. Code C122469.

The group of professions that include bailiffs, correctional officers, and jailers; detectives and criminal investig ators; fish and game wardens; parking enforcement workers; and police officers. 